\title{
Case for diagnosis ${ }^{*}$
}

Camila Bueno Requena ${ }^{1}$

Mariângela Esther Alencar Marques ${ }^{1}$

\author{
Hélio Amante Miot ${ }^{1}$ \\ Luciane Donida Bartoli Miot ${ }^{1}$
}

\section{CASE REPORT}

Twenty-two year-old Caucasoid male, employed at the maintenance sector at UNESP Botucatu, reported that 18 months ago he perceived a progressive thickening on the bases of his fingers, without other localized symptoms. He denied systemic signs or symptoms and did not present relevant personal antecedents. The patient reported the habit of frequently manipulating his fingers during situations of anxiety. Clinical examination showed enlargement and thickening of the skin (papillosis) of the proximal interphalangeal joints of $2^{\text {nd }}, 3^{\text {rd }}$ and $4^{\text {th }}$ right fingers and proximal interphalangeal joints of $2^{\text {nd }}, 3^{\text {rd }}$, $4^{\text {th }}$ and $5^{\text {th }}$ left fingers, with additional thickening of $5^{\text {th }}$ right finger distal interphalangeal joint (Figures 1 and 2). Histopathological examination revealed hyperkeratosis, discreet papillomatosis, slight increase in fibroblasts and dermal mucinosis (Figure 3). Radiography of the hands demonstrated no bone or periosteal involvement, routine biochemical tests, blood glucose, and serum growth hormone were within the normal range.

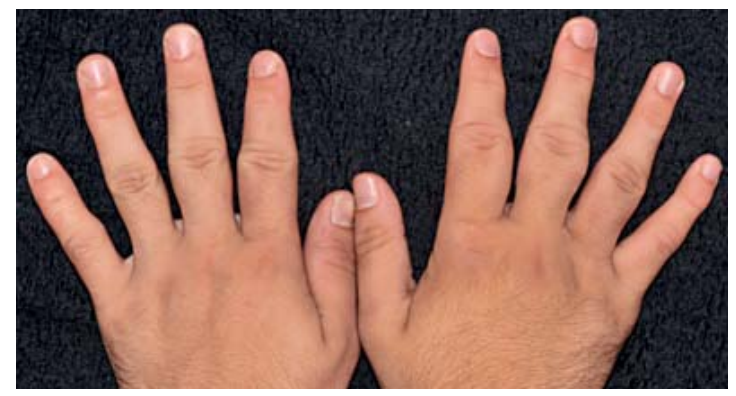

FIGURE 1: Increased volume and thickening of proximal skin on the fingers. Note the greater severity of the condition on the right hand and on the $2^{\text {nd }}$ and $3^{\text {rd }}$ fingers

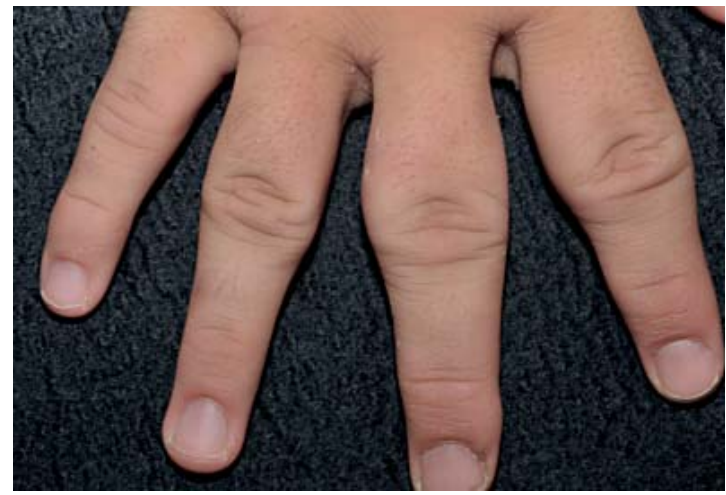

FIGURE 2: Detail of cutaneous thickening, discrete papillosis of interphalangeal joints' dorsum and increase in the volume on fingers' bases
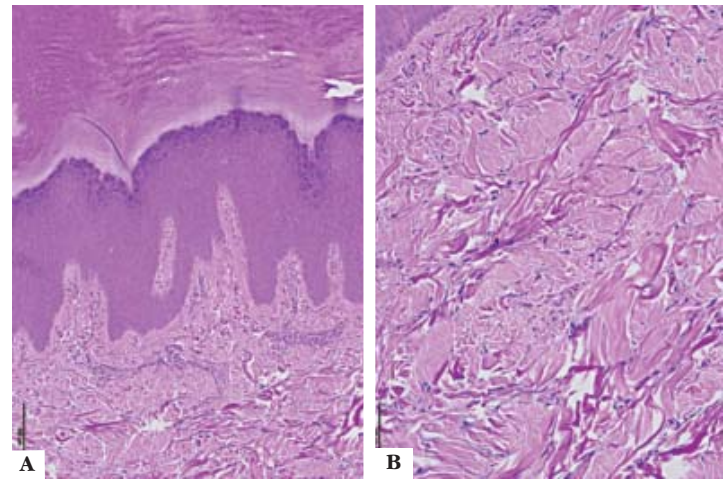

FIgURE 3: Histopathological examination: (A) skin with acanthosis, hyperkeratosis and, in detail, (B) absence of inflammatory process in the dermis with fibroblast proliferation (H\&E, 100x and 200x)

Received on 11.04.2013.

Approved by the Advisory Board and accepted for publication on 24.04.2013.

Work performed at the Dermatology and Radiology Department at Botucatu Medical School - Paulista State University "Júlio de Mesquita Filho" (UNESP)Botucatu (SP), Brazil.

Conflict of interest: None

Financial funding: None

Paulista State University "Júlio de Mesquita Filho" (UNESP) - Botucatu (SP), Brazil 


\section{DISCUSSION}

Pachydermodactyly is a rare and benign form of digital fibromatosis characterized by asymptomatic expansion of soft tissue around the proximal phalanges and interphalangeal joints. ${ }^{1}$ Less than 150 cases have been described so far, in four continents. It is more prevalent among adolescents and young males. ${ }^{2}$

Etiology remains unknown and the disease is usually acquired, although some authors have documented familial cases. It is suggested that repeated mechanical trauma such as the habit of interlacing or rubbing fingers, would lead to skin thickening, configuring it as a factitious dermatosis of compulsive basis. ${ }^{3-5}$

In most cases, it affects the $2^{\text {nd }}, 3^{\text {rd }}$ and $4^{\text {th }}$ fingers. There may be lichenification of the skin over the lesion, erythema and desquamation, and the lesion may become painful. The process can extend to the metacarpophalangeal joints, characterizing transgrediens pachydermodactyly. ${ }^{6}$

Pachydermodactyly has been described in association with Dupuytren's contracture, Asperger syndrome, Ehlers-Danlos syndrome, carpal tunnel syndrome and tuberous sclerosis. Differential diagnosis should be made with pachydermoperiostosis, acropachydermodactyly in psoriasis, multiple osteitis cystoides, fibrous tumor, acromegaly, chronic juvenile arthritis, synovitis, subcutaneous granuloma annulare, rheumatoid nodules, gouty tophus, xanthomato- sis, fibrosarcomas, juvenile fibromatosis, lichen myxedematosus and phalangeal pad, to which it can be associated. $^{7}$

Histologically, there is hyperkeratosis, acanthosis, thickening of the dermis, increase in fibroblasts and collagen deposits (I, III and V), increase in the thickness of basal membrane and of eccrine sudoriparous glands, intense deposition of mucopolysaccharides, poor demarcation between the papillary and reticular dermis, eosinophilia and lymphocytic infiltrate. There is evident mucin deposition. ${ }^{1.8}$

Laboratory exams do not show specific changes. Radiological exams show the increased volume of soft tissue, without bone, tendon or capsular changes, although repeated trauma may induce interphalangeal subluxation and functional deficit., ${ }^{910}$

Described therapies include: surgical removal, intralesional triamcinolone infiltration and self-control techniques to decrease the friction secondary to fingers' manipulation. ${ }^{1,2,89}$ In this patient, the lesions partially regressed after suspending the trauma to the fingers, at 30-day follow-up.

Dermatologists should be aware of this diagnosis, because of the opportunity to detect and intervene in a dermatosis of compulsive origin, since chronic manipulation of the fingers can lead to osteoarticular deformities. ${ }^{10} \square$

Abstract: Pachydermodactyly is a rare and benign form of acquired digital fibromatosis characterized by the expansion of soft tissue around proximal phalanges and interphalangeal joints. The etiology remains unknown, although it is suggested that repetitive mechanic trauma like the interlacing or rubbing of the fingers can lead to skin thickening. We report a case of a young man with skin thickening around interphalangeal joints and compulsive finger manipulation habit. The histopathology disclosed hyperkeratosis, discrete papillomatosis, mild increase of fibroblasts and dermal mucinosis. The lesions regressed partially, after finger manipulation was stopped.

Keywords: Dermatology; Obsessive-compulsive disorder; Primary hypertrophic osteoarthropathy

\section{REFERENCES}

1. Al Hammadi A, Hakim M. Pachydermodactyly: case report and review of the literature. J Cutan Med Surg. 2007;11:185-7.

2. Prieto D, Gallego E, López-Navarro N, Matilla A, Herrera-Ceballos E. Pachydermodactyly: an uncommon acquired digital fibromatosis. J Clin Rheumatol. 2011;17:53-4.

3. Birman MV, Lee DH. Factitious disorders of the upper extremity. J Am Acad Orthop Surg. 2012;20:78-85

4. Lautenschlager S, Itin PH, Rufli T. Pachydermodactyly: reflecting obsessive-compulsive behavior? Arch Dermatol. 1994;130:387.

5. Cabanillas M, Monteagudo B, León-Muíños E, Suárez-Amor 0 . Pachydermodactyly in a young girl: cutaneous manifestation of a psychiatric disorder? Pediatr Dermatol. 2010;27:306-8.

6. Vale LR, Coeli FR, Michalany N, Hassun KM, Porro AM. Transgrediens pachydermodactyly: report of a case. An Bras Dermatol. 2009;84:190-3.

7. Pereira JM, Pereira FCN, Pereira VCN. Interphalangeal pads on pachydermodactyly. An Bras Dermatol. 2004; 79:313-21.

8. Hunt R, Mandal R, Walters R, Schaffer JV. Pachydermodactyly. Dermatol Online J. 2010;16:5.
9. Sandobal C, Kuznietz A, Varizat A, Roverano S, Paira S. Pachydermodactyly: four additional cases. Clin Rheumatol. 2007;26:962-4.

10. Taylor-Gjevre R, Saxena A, El Maadawy S, Classen D, Nair B, Gjevre J. A case of deforming pachydermodactyly. J Clin Rheumatol. 2009;15:78-80.

MAILING ADDRESS:

Hélio Amante Miot

Departamento de Dermatologia e Radioterapia da

Faculdade de Medicina de Botucatu da Universidade

Estadual Paulista (UNESP) - Botucatu

18618-000 - São Paulo - SP

Brazil

E-mail: heliomiot@fmb.unesp.br

How to cite this article: Requena CB, Miot HA, Marques MEA, Miot LDB. Case for diagnosis. Pachydermodactyly. An Bras Dermatol. 2014;89(2):359-60. 